FEDERAL RESERVE BANK OF SAN FRANCISCO

WORKING PAPER SERIES

\title{
Investment Behavior of U.S. Firms over Heterogeneous Capital Goods: A Snapshot
}

\author{
Daniel J. Wilson \\ Federal Reserve Bank of San Francisco
}

March 2006

Working Paper 2004-21

http://www.frbsf.org/publications/economics/papers/2004/wp04-21bk.pdf

The views in this paper are solely the responsibility of the authors and should not be interpreted as reflecting the views of the Federal Reserve Bank of San Francisco or the Board of Governors of the Federal Reserve System. This paper was produced under the auspices for the Center for the Study of Innovation and Productivity within the Economic Research Department of the Federal Reserve Bank of San Francisco. 


\title{
Investment Behavior of U.S. Firms over Heterogeneous Capital Goods: A Snapshot
}

\author{
Daniel Wilson (Federal Reserve Bank of San Francisco) ${ }^{1}$
}

Draft: March 2006

\footnotetext{
${ }^{1}$ Economist, Federal Reserve Bank of San Francisco, 101 Market St., MS 1130, San Francisco, CA 94105; (415) 974-3423 (office), (415) 974-2168 (fax); Daniel.Wilson@sf.frb.org (email). Geoffrey MacDonald provided superb research assistance. This paper benefitted from helpful comments from Bob Chirinko, Mark Doms, Bart Hobijn, Kevin Stiroh and seminar participants at the FRBSF and Center for Economic Studies (Census). The research in this paper was conducted while the author was a research associate at the CES and California Census Research Data Center (CCRDC); special thanks go to Ritch Milby of the CCRDC. Research results and conclusions expressed are those of the author and do not necessarily indicate concurrence by the Bureau of the Census, the CES, or the Federal Reserve System. This paper has been screened to ensure that no confidential data are revealed.
} 


\begin{abstract}
Recent research has indicated that investment in certain capital types, such as computers, has fostered accelerated productivity growth and enabled a fundamental reorganization of the workplace. However, remarkably little is known about the composition of investment at the micro level. This short paper takes an important first step in filling this knowledge gap by looking at the newly available micro data from the 1998 Annual Capital Expenditure Survey (ACES), a sample of roughly 30,000 firms drawn from the private, nonfarm economy. The paper establishes a number of stylized facts. Among other things, I find that in contrast to aggregate data the typical firm tends to concentrate its capital expenditures in a very limited number of capital types, though which types are chosen varies greatly from firm to firm. In addition, computers account for a significantly larger share of firms' incremental investment than they do of lumpy investment. [Keywords: Capital Heterogeneity, Investment; JEL Codes D21, D24, D29.]
\end{abstract}




\section{Introduction}

Very little is known about firms' disaggregate investment behavior. Economists' priors regarding the composition of investment at the firm level have been based primarily on economy-wide or industry-level capital flows information. These latter data can say little about the degree of microeconomic heterogeneity in investment composition. Is the composition of investment, and thus perhaps the quality of investment and capital, relatively constant across firms within an industry or do firms in the same industry tend to choose considerably different types of assets to invest in. Recent research has shown that the composition of investment can be vital to understanding investment dynamics over the business cycle (Tevlin and Whelan (2003)) as well as capital's role in explaining productivity differences (Caselli and Wilson (2004), Wilson (2004)).

Moreover, priors based on economy-wide or industry-level data may be inaccurate for a couple of reasons. First, there is no reason to expect the capital flows patterns of individual firms to be similar to those at the aggregate level. This is particularly true in light of the growing body of evidence regarding heterogeneity at the micro level in terms of total-factor productivity, employment, and total investment (Haltiwanger (1997), Davis, et al. (1996), Caballero, et al. (1995)). Numerous studies have shown that aggregate measures, even up built up from microeconomic data, often mask important variations in the measures at the micro level. For example, investment at the aggregate level is fairly smooth over time despite enormous lumpiness at the micro level (Doms and Dunne (1998), Caballero, et al. (1995)).

The second reason to be skeptical of priors concerning firm behavior based on industry-level capital flows data is that these data, at least in the U.S., are in fact not currently based on micro source data. The U.S. capital flows tables, constructed by the Bureau of Economic Analysis (BEA), are instead primarily based on occupational employment distributions combined with data on the aggregate supply of asset-specific capital and aggregate investment by industry. ${ }^{1}$ The basic idea is as follows: when estimating computer investment by the Finance industry, the BEA starts with total value of shipments of computers (from the Annual Survey of Manufacturers), subtracts off estimates of net exports and purchases of computers by consumers and governments to get domestic supply, and then assigns a fraction of domestic supply to Finance in

\footnotetext{
${ }^{1}$ See Becker, Haltiwanger, Jarmin, Klimek, and Wilson (2005) for a discussion of these BEA data and a comparison to potential alternative capital flows tables based on the 1998 ACES.
} 
proportion to Finance's share of total computer programmers' employment. This resulting investment value may be further adjusted to be consistent with source data on total investment by the Finance industry. Inferring capital flows from occupational employment matrices relies on extremely restrictive conditions that are unlikely to hold in reality. The fact that U.S. capital flows data may come as a surprise to many readers since these data are widely used by researchers.

Both of the above problems are due to a previous lack of data on disaggregate investment at the micro level. This has changed, however, with the full-scale introduction of asset-type detail in the Census Bureau's Annual Capital Expenditures Survey (ACES) in 1998. (This asset-type detail was also collected in the 2003 ACES, which was not yet available at the time of this writing.). The 1998 ACES is unique as the only large-scale micro-level U.S. survey of investment that disaggregates investment into a full range of detailed asset types (i.e., beyond simply total equipment and total structures, and beyond just one or two asset types such as computers or transportation equipment). These rich data on disaggregate investment offer a point-in-time snapshot of investment composition choices by a large number of firms spanning the U.S. private nonfarm economy.

This short paper uses the 1998 ACES micro data file to present some of the first evidence on firm-level, cross-sectional patterns regarding capital mix. First, I find substantial differences in investment composition across firms, even within narrowlydefined industries. Second, certain capital types (e.g., Computers, Software, Furniture, General Purpose Machinery) ${ }^{2}$ are shown to be used across a wide range of industries, indicating that they are general purpose capital goods. Third, I find evidence that certain types of capital goods tend to be bundled, i.e., purchased in conjunction with each other. Here, I focus on Computers, given recent work showing computers' importance for productivity growth (e.g., Wilson (2004); Gilchrist, et al. (2004); Brynjolfsson \& Hitt (2003); Oliner \& Sichel (2000)). I find that Computers tend to be purchased in conjunction with Software, Scientific Instruments, and Furniture, among other types. Fourth, it is shown that the typical firm tends to concentrate its capital expenditures in a very limited number of capital types. However, which types are chosen varies greatly from firm to firm. Lastly, I find that investment that takes place during lumpy investment episodes, or "spikes", identified at the firm level, has a systematically different

\footnotetext{
${ }^{2}$ Throughout the paper, capital type names are capitalized to indicate that they refer to specific categories of capital listed in the Annual Capital Expenditures Survey.
} 
composition than that of incremental investment. Specifically, Computers account for a significantly larger share of firms' incremental investment than of lumpy investment.

These findings have important implications in terms of the economic modeling of production, business cycle dynamics, and optimal public policy. Most economic models of production or investment assume a single capital stock, or perhaps one for equipment and one for structures. The finding in this paper that the composition of capital varies greatly across firms strongly suggests that these models may be misspecified, especially in light of recent research showing that the composition of capital is an important factor in production. ${ }^{3}$ As our economic models evolve to incorporate the effects of capital composition, a solid understanding of the patterns of disaggregate investment at the micro level will be key. This paper is an important first step in providing that understanding.

In terms of business cycle dynamics, the finding that the composition (e.g., computers' share of investment) of investment during investment spikes is significantly different from that of incremental investment, coupled with the previously established fact that microeconomic spikes comprise a large portion of aggregate investment during booms, suggests that capital composition and quality may vary importantly over the business cycle. For instance, if capital quality tends to be higher for incremental investment, and incremental investment is a lower share of aggregate investment during booms, then the volatility of quality-adjusted capital over the cycle may be less than previously thought.

Lastly, the findings in this paper may have implications for public policy, particularly tax policy. For instance, policymakers in the U.S. often enact special accelerated depreciation allowances for certain capital types (e.g., high-tech equipment) as temporary measures aimed at spurring an economic recovery. Because the composition of investment varies greatly across firms and industries, these special allowances will benefit certain firms and industries more so than others. The non-uniform incidence of these allowances likely is not fully appreciated by policymakers. Furthermore, if high-tech equipment comprise a larger share of investment during recessions (when incremental investment is predominant), then targetting this type of equipment with special allowances may in fact be optimal.

\footnotetext{
${ }^{3}$ See, e.g., Cummins \& Dey (1998), Jorgenson and Stiroh (2000), Caselli and Wilson (2004), and Wilson (2004).
} 


\section{Data}

\subsection{Annual Capital Expenditures Survey}

The principal source of data for this paper is the 1998 Annual Capital Expenditures Survey (ACES). ${ }^{4}$ The ACES is conducted annually by the U.S. Census Bureau to elicit information on capital expenditures by U.S. private, nonfarm companies. The annual ACES data are used by the BEA in constructing the National Income and Product Accounts (NIPA).

In typical years, the ACES queries companies on their expenditures on total equipment and total structures, in addition to related values such as book value of capital assets, accumulated depreciation, retirements, etc.. In the 1998 survey, however, the ACES additionally required firms to report their investment broken down by 55 separate types of capital - 26 types of equipment and 29 types of structures. These data on disaggregate investment allow one to observe the complete composition of firms' investment.

In fact, the survey requests firms to break out their capital expenditures in this way separately for each of the industries in which they operate. Except in Section 3.4, the analyses in this paper are based on the ACES data as aggregated to the firm-level.

The 1998 ACES sampling frame consists of all U.S. private, nonfarm employers. ${ }^{5}$ All companies with 500 or more employees were surveyed while smaller employers were surveyed based on a stratified random sampling such that larger firms were sampled with a higher probability. Response to the ACES is legally required so response rates are extremely high. The final sample consists of nearly 34,000 firms, of which approximately half have 500 or more employees. 27,712 firms in the sample had nonzero investment. Except where otherwise noted, all of the analysis in this paper will be based on this sample of firms with non-zero investment.

\footnotetext{
${ }^{4}$ For more details regarding the 1998 Annual Capital Expenditures Survey, including the published aggregate data and the actual survey questionaires, see Census Bureau (2000).

${ }^{5}$ In addition, a sample of companies with zero employees were sent an abbreviated questionaire which did not request the disaggregate investment detail.
} 


\section{Cross-Sectional Patterns of Firm-Level Investment Behavior}

In this section, I utilize the 1998 ACES microdata to answer the following interesting and previously unexplored questions related to disaggregate investment behavior:

1. How extensive is investment in specific asset types?

2. How intensive is investment in specific asset types?

3. What is the range of industries using each asset type?

4. To what extent does investment composition vary across sectors/divisions within a parent firm?

5. To what extent are different asset types purchased in conjunction? Specifically, what asset types tend to be purchased in conjunction with computers?

6. How "lumpy" is investment in the asset-type dimension? I.e., do firms tend to invest in a wide range of asset types or just a few?

7. Is the composition of investment different during investment spikes than during periods of incremental investment?

\subsection{The Extensive Margin of Asset-Specific Investment}

Whether or not a firm decides to invest in a particular capital good can be thought of as the extensive margin of the investment decision. (The intensive margin, how much of the capital good to actually purchase or lease, is analyzed in the next subsection). Columns (1) and (2) of Table 1 give the proportion of sample firms that report purchasing each type of capital. Column (2) gives the unconditional proportion; Column (2) gives the proportion conditional on firms having non-zero investment in the capital type's broad asset class (equipment or structures).

Computers are the most common type of investment, with over $55 \%$ of firms purchasing at least some computers or computer peripheral equipment. This share jumps to $71 \%$ if one excludes firms that have no equipment investment at all. At first blush, it would appear that the propensity to invest in Computers is higher for manufacturing firms: $59 \%$ compared to $54.5 \%$ for non-manufacturing (not shown). 
However, this difference is primarily because non-manufacturers are simply less likely to invest in equipment at all (75\% of non-manufacturing firms had positive equipment investment compared to $90 \%$ of manufacturing firms). Among equipment-buying firms, $72 \%$ of non-manufacturers invested in Computers while $66 \%$ of manufacturers did so.

It is interesting to compare these numbers on computer investment to analogous statistics reported by Dunne, Foster, Haltiwanger, and Troske (2002). Dunne, et al. find that the proportion of manufacturing plants in the Annual Survey of Manufacturers (ASM) reporting positive computer investment rose from about 10\% in 1977 to just over $60 \%$ by 1992 . Again, I find the proportion among manufacturing firms in 1998 to be $59 \%$. The Dunne, et al. numbers are likely overestimated, however, since about $40 \%$ of sampled ASM plants did not respond to the computer question in the ASM survey. Non-respondents are arguably far more likely to have zero computer investment than the respondents. Thus, the upward trend in the proportion of firms (or plants) investing in computers likely continued between 1992 and 1998.

After computers, the next most common types of investment are Furniture (31\%), Office Equipment (24\%), Autos (24\%), Communications Equipment (21\%), Special Industry Machinery (16\%), General Purpose Machinery (16\%), Office Buildings (15\%), Software (14\%), and Manufacturing Plants (12\%). All other types were purchased by less than $10 \%$ of the sample.

What is striking about these results is that, with the exception of computers, all other capital types have frequencies will below $50 \%$. In other words, for any particular non-computer asset type, a randomly-selected firm is more likely than not to have zero investment. The surprising infrequency of investment in non-computer asset types suggests that these asset types either have large non-convex adjustment costs or that they are characterized by substantial indivisibilities.

\subsection{The Intensive Margin of Asset-Specific Investment}

In this subsection, I characterize the intensive margin of asset-specific investment by computing each asset types average share of total firm investment. Columns (3) and (5) of Table 1 show the cross-firm, weighted-average of each asset type's share of firm total investment (standard deviations are shown in Columns (4) and (6)). Observations are weighted by sample weight (inverse of sampling probability, adjusted for nonresponses) which is necessary given the stratification of the ACES sampling design. Column (3) 
gives the asset type's average share of firms' total investment while Column (5) gives the asset type's average share of its broad asset class (total equipment or total structures). The asset types in the table are sorted by average share of total investment.

Computers are nearly one-third of total (and equipment) investment for the average firm, a much higher share than that of any other capital good. Hence, not only are Computers the most common type of investment as discussed above, they are also the largest share of investment on average. The next largest type of investment tends to be Autos, which, on average, comprise about one-eighth of firm total (and equipment) investment. Interestingly, the fact that Computers are a much larger average share of investment than Autos is in sharp contrast to the picture one gets from the aggregate data. According to the published aggregate ACES data (and similarly for BEA capital flows data), Autos actually comprised a larger share of economy-wide investment in 1998 than did Computers: 17\% of equipment compared to $14 \%$ for Computers. This contrast between the aggregate and firm level shares reveals that firms that are large (in terms of total investment) tend to invest more intensively in autos than computers, while the opposite is true for small firms.

Other capital goods that make up at least $5 \%$ of the average firm's total investment are Furniture (7.9\%); Office Buildings (7.7\%); Other Office Equipment (6.2\%); Plants (5.2\%); and General Purpose Machinery (5.0\%).

It should be noted that a small average investment share could arise either from a large number of firms having a small investment share or from a small number of firms having a large investment share (while the rest of firms are near zero). The latter tends to be the case for structures while the former tends to the case for equipment types. For example, "Other Commercial Stores/Buildings, NEC" averages a relatively high $4.5 \%$ of total investment (9th most out of the 55 types) even though less than $2 \%$ of the sample invested in this type of structure. In contrast, $13.6 \%$ of the sample purchased software but software accounted for less than $1 \%$ of the average firm's investment.

Part of the reason for the high frequency of software investment coupled with its low average share - lower than software's aggregate investment share in the NIPAs - is that the ACES software category is narrower than that of the NIPAs. In the ACES, firms are instructed to report investment in software "only if capitalized as part of a tangible asset" and to exclude it "if the purchase is considered intangible (e.g., licensing agreement) or if expensed such as office supplies." The NIPAs, on the other hand, classify all software expenditures as investment regardless of whether the 
firm accounts for the expenditures as capital or intermediate expenses. (Note that software that is bundled with, or embedded in, hardware is not counted as software investment in either ACES or NIPAs.) The fact that Capitalized Software Purchased Separately, on average, comprises a very small share of firms' investment even though a considerable percentage of firms purchase it may be partially because firms purchase this kind of software in conjunction with other kinds of software (including expensed software). Hence, the average investment share for Capitalized Software Purchased Separately is likely well below the average share for total software, while the measured percentage of firms investing in this kind of software is probably near that for total software.

\subsection{Range of Industries Investing in Each Asset Type}

The third interesting question that can be answered with these data is: how broadly is each capital good used (or at least purchased)? The pervasiveness of investment in an asset type across a wide range of industries has been cited as a defining characteristic of a general purpose technology (Bresnahan and Trajtenberg (1996)). A simple statistic that the range of use across industries is the investment concentration ratio by the top four investing industries (at the 3-digit SIC level). Specifically, I compute the fraction of economy-wide investment in a given capital type that is accounted for by the four industries with the highest levels of investment in that type. A low value for this "top-4 concentration ratio" indicates that the capital good is used across a wide range of industries.

Table 2 gives the top- 4 concentration ratio for each capital type. The types of equipment found to have the widest range of use are generally those one would intuitively expect to be general purpose: Computers, Other Office Equipment, Software, Fabricated Metal Products, General Purpose Machinery, Autos, and Furniture. Perhaps less intuitive, I also find Metalworking Machinery and Medical Equipment to have widespread use. Interestingly, Communications Equipment does not appear to be used broadly across industries - its top- 4 concentration ratio is $87 \%$. Structures, as one might expect, generally have much higher concentration ratios then equipment, reflecting the more specialized functions that structures have. An exception is Manufacturing, Processing, and Assembly Plants, which tend to be purchased by firms in many different industries.

These results confirm the common perception that computers and software are 
general purpose capital goods, while they refute the perception that communications equipment are as well. It should be noted that this is not the first paper to report evidence computers and software are general purpose technologies. Cummins and Violante (2002), Jovanovic and Rousseau (2005), and others have shown the wide range of use of these technologies across industries. Their evidence, however, is based on the BEA capital flows data, which, as mentioned in Section 1, are not based on micro source data.

\subsection{Analysis of Cross-Sectional Variance}

The results in this and previous studies strongly suggest that investment is heterogeneous at the micro level. For instance, above we established that the composition of investment (measured by assets' shares of firm total investment) varies greatly across firms, even within 3-digit industries. Thus, a natural question is whether investment composition also varies greatly across industry divisions within a firm. That is, how much of the variation in an asset type's share of investment is due to differences across divisions within a firm as opposed to differences across firms? As mentioned in Section 2, the ACES data is actually collected at the level of industry divisions within the firm, so it is possible to to answer this question. To do so, I perform a variance decomposition on each asset type's share of firm-division level investment into its within- and between-firm components. I perform this decomposition both unconditionally and conditioning on firms having multiple divisions.

The results show, first, that very little of the total firm-division level variance in a capital type's investment share (for any capital type) is within-firm. Conditional on firms having multiple divisions, the ratio of within-firm to total variance ranges across asset types from 0.01 to 0.39 . For equipment, the median (and mean) ratio is 0.27 ; for structures, the median ratio is 0.26 (mean is 0.22 ). The unconditional ratios are much lower (median is 0.12 for equipment and 0.13 for structures). Thus, a substantial majority of the variance in investment shares is between-firm, suggesting that establishments/divisions within firms tend to be fairly homogenous in terms of their capital composition. 


\subsection{Bundling of investment: The Case of Computers}

Capital goods are not used in isolation. They typically are used together as part of a system of capital infrastructure. This should be especially true for general purpose capital goods such as computers. Table 3 provides evidence of what capital types tend to be purchased in conjunction with, or instead of, computers. Specifically, for each capital type, I calculate the partial correlation between the computer investment share and that type's investment share, controlling for 3-digit industry effects. Table 3 provides the weighted correlations for those types that have a statistically significant partial correlation with computers. Observations are weighted by sample weight (unweighted correlations, not shown, are very similar).

Among equipment, Computers tend to be purchased in conjunction with Other Office Equipment; Scientific Instruments; Software; Aerospace Products; Furniture; and Artwork, Books, \& Other Equipment, NEC. Capital goods that generally are purchased separately from Computers are Communications Equipment; Metalworking Machinery; Special Industry Machinery; Cars and Light Trucks; Heavy-Duty Trucks; Engine, Turbine, and Power Transmission Equipment; Electrical and Distribution Equipment; Mining and Oil \& Gas Field Machinery; and Miscellaneous Equipment. The negative correlation with Communications Equipment is surprising and counterintuitive. This result may reflect that communications equipment typically is embedded in business computer equipment (and hence is recorded as computer investment) and therefore separate investment in communications equipment is unnecessary.

Among structures, Computers are most often purchased with Office, Bank, \& Professional Buildings; Multi-Retail Stores; and Other Commercial Buildings/Stores, NEC. On the other hand, firms with capital expenditures on the following types of structures tend not to purchase Computers in the same year: Industrial Nonbuilding Structures; Automotive Facilities; Air, Land, \& Water Transportation Facilities; Telecommunications Facilities; Electric, Nuclear, \& Other Power Facilities; Petroleum \& Natural Gas Wells; and Other Mining \& Well Construction.

\subsection{Investment Variety}

It is well documented that investment is extremely lumpy over time at the microeconomic level (see, e.g., Doms and Dunne (1998) and Power (1999)). However, we know little about the microeconomic "lumpiness," or concentration, of investment over cap- 
ital types. The question is: in a given year, do firms tend to invest only in a small number of capital types or do they spread their investment dollars across a wide variety of types?

To answer this question, for each firm I calculated the number of asset types in which the firm reported positive investment. Figures $1 \mathrm{a}$ and $1 \mathrm{~b}$ show the cross-sectional distribution of this number across the firms in our sample. Figure 1a gives the distribution for equipment; Figure 1b gives the distribution for structures. Of the 21,686 firms that reported positive equipment investment, a little less than $30 \%$ of investing firms reportedly purchased only one type of equipment. $16 \%$ reported investment in two types, $15 \%$ in three types, $12 \%$ in four types, and $9 \%$ in five types. The frequencies decline with the number of reported types (though, for non-disclosure purposes, the tail of the distribution is truncated at 18-23 types). The average equipment-purchasing firm reported investment in 3.4 types of equipment.

As expected, investment in structures tends to be highly concentrated. In fact, $72 \%$ of the 10,782 firms that reported positive structures investment invested in just one type of structure. $16 \%$ reported investing in two types, almost $7 \%$ reported investing in three types, and the frequencies continue to decline thereafter with the number of types. The average number of structure types that firms invested in (conditional on having positive structures investment) was 1.5.

An alternative way to assess how concentrated or diversified firm level investment is is to compute the proportion of the sample that invested in three (e.g.) or more capital types (within the broad asset class, equipment or structures). I call this statistic the $3+$ equipment (structures) share. For the entire sample (of 27,712 firms), the $3+$ equipment share is $42.8 \%$ and the $3+$ structures share is $4.3 \%$. For the subsample of firms with non-zero equipment investment, the $3+$ equipment share is $54.7 \%$; for the subsample of structures-buying firms, the $3+$ structures share is $11.1 \%$.

The variety of firms' investments does of course vary by firm size. Table 4 shows, separately for equipment and structures, the mean number of types in which firms invest and the $3+$ share. For both equipment and structures, I find that larger firms tend to invest in a larger variety of capital goods. This is not surprising considering that larger firms tend to be more diversified in terms of their business operations and hence more diversified in terms of their physical capital needs. ${ }^{6}$

\footnotetext{
${ }^{6}$ As discussed below, there is the possibility that firms with positive but near-zero investment in a type report that investment as zero. This may be more problematic for smaller firms since they are
} 
I also briefly note here that investment variety also varies noticeably by industry. It appears that quasi-public industries, such as educational services, utilities, pipelines, and water services, and finance industries tend to report investment in the most number of types.

The low number of types that most firms report investing in, especially for structures, in part may reflect inaccuracy on the part of respondents. That is, decomposing their firm's capital expenditures into a large number of disaggregate asset types may impose an exorbitant time and record-keeping burden on respondents. It is difficult to determine with certainty whether respondents truncate the number of asset types for which they report investment, but it may contribute to measurement error in the investment shares.

Nonetheless, the fact that $72 \%$ of firms report investment in only a single structure type, combined with the fact (established in Table 1) that no single structure type comprises more than a quarter of the average firm's investment in structures, suggests that firms tend to concentrate construction investment on a single type of structure but that this type differs from firm to firm. ${ }^{7}$ The particular type of investment a firm chooses appears to be primarily determined by the industry to which the firm belongs, as evidenced by the high concentration ratios in Table 2.

\subsection{The Composition of Spikes versus Incremental Investment}

As mentioned above, it is well known that much investment at the micro level takes place in spikes rather than smooth incremental investment. A number of macroeconomic models build on this micro evidence to explain aggregate investment dynamics [e.g., Caballero and Engels (1999)]. It generally is assumed that the investment occuring in spikes and the investment occuring in increments are of the same qualitative nature. In particular, it is assumed that there is no difference in quality, i.e., the

more likely to have near-zero investment and also to have less-developed accounting systems. Thus, part of the correlation between firm size and reported investment variety may be due to misreporting.

${ }^{7}$ This finding is consistent with the theoretical model of optimal adoption of complementary capital goods by Jovanovic and Stolyarov (2000). They show that given fixed costs of investment, the firm may invest in complementary capital goods asynchronously rather than simultaneously. Thus, the finding that firms tend to concentrate their structures investment, which should involve higher fixed costs than equipment investment, on a single type but that this type differs across firms is consistent with their theory. A test of this theory would require a time dimension to these data: a finding that the concentrated type differs across time within firms would support the theory. 
capital-embodied technology, between lumpy and incremental investment. If there is a difference, however, the true (i.e., quality-adjusted) lumpiness of investment could in fact be much different than is currently assumed.

To assess whether the quality composition of investment spikes is fundamentally different from that of incremental investment, I start with the firm-level investment share for each asset type. I then split the sample into firms that engaged in an investment spike (in terms of total investment) in 1998 and those that did not. Lastly, I compute the weighted-average investment share by type for each subsample (weighting each firm by its total investment) and perform a two-sample equality-of-the-means ttest.

The most common definition of an investment spike used in the literature [e.g., Doms and Dunne (1998) and Powers (1999)], and thus the definition I use, is the following:

$$
\begin{aligned}
& \text { Spike }_{i t}=1 \text { if } I_{i t} / K_{i, t-1}>0.20, \\
& \text { Spike }_{i t}=0 \text { otherwise, }
\end{aligned}
$$

where $i$ indexes firms, $I_{i t}$ denotes total investment, and $K_{i, t-1}$ denotes total beginningof-year book value of capital. ${ }^{8}$

For most types, the mean investment share does not differ importantly between the two samples. A notable exception, however, is Computer investment: Computers comprise $14 \%$ of incremental investment, on average, whereas Computers comprise just $12 \%$ of investment spikes. This difference is statistically significant at below the $1 \%$ level. Note this result is robust to controlling for 3-digit SIC industry (by demeaning investment shares by industry mean prior to computing the group means).

That computers represent a larger share of investment in periods of incremental investment could be because firms are locked into particular production processes that require a stable level of computer capital stock, making computer investment less cyclical than other types of capital. Regardless of the explanation, the result has at least two important implications. At the aggregate level, given that investment spikes are far more common during business cycle booms than during troughs, this result suggests that computers' share of the aggregate capital stock is countercyclical. Computers' share of capital has been shown to be important for understanding

\footnotetext{
${ }^{8}$ For the sample used in this paper, $t$ is of course 1998. Note that though the data are for 1998 only, $K_{i, t-1}=K_{i, 1997}$ is observed since beginning-of-year book value of capital is reported.
} 
aggregate investment behavior since computer investment may be more sensitive to the user cost of capital (see Tevlin and Whelan (2003)). Another implication is that, given computer investment likely embodies more technology per dollar than other types of investment (see Wilson (2004) for evidence of this), investment in constant-quality units may actually be less lumpy at the micro level than previously thought.

\section{Conclusion}

The preceding section began by posing seven previously unanswered questions regarding micro-level investment behavior across heterogeneous asset types. Here I summarize what we have learned here from the 1998 ACES microdata.

1. How extensive is investment in specific asset types?

The data show that only investment in computers could be reasonably be characterized as extensive or common. For all other capital types, investment is in fact a rare phenomenon, with far less than half of firms investing in a given year (to the extent that 1998 is a representative year).

2. How intensive is investment in specific asset types?

Computers also are found to be the most intensively-purchased capital good, accounting for about one-third of firm investment for the average firm. Investment intensity is much less for all other types, though Autos, Furniture (7.9\%), Office Buildings (7.7\%), Other Office Equipment (6.2\%), Plants (5.2\%), and General Purpose Machinery (5.0\%) on average account for at least five percent of firm investment.

3. What is the range of industries using each asset type?

The asset types that tend to be used by a wide range of industries are: Computers, Other Office Equipment, Software, Fabricated Metal Products, General Purpose Machinery, Autos, Furniture, and, surprisingly, Metalworking Machinery and Medical Equipment. Types of structures, on the other hand, tend to be rather industry-specific.

4. To what extent does investment composition vary across sectors/divisions within a parent firm? 
Interestingly, compared with cross-firm variation, the composition of investment across asset types varies very little across industry divisions within a firm. This finding suggests that the vast majority of the variation across individual establishments in terms of investment and capital composition likely is between firms and not within firms. This in turn suggests that firm-level data should suffice for analyses related to investment quality/composition.

5. To what extent are different asset types purchased in conjunction? Specifically, what asset types tend to be purchased in conjunction with computers?

Computers often are purchased in conjunction with Other Office Equipment; Scientific Instruments; Software; Aerospace Products; Furniture; and Artwork, Books, \& Other Equipment, NEC, while the following goods tend not to be purchased separately: Metalworking Machinery; Special Industry Machinery; Cars and Light Trucks; Heavy-Duty Trucks; Engine, Turbine, and Power Transmission Equipment; Electrical and Distribution Equipment; Mining and Oil \& Gas Field Machinery; Miscellaneous Equipment; and, surprisingly, Communications Equipment.

6. How "lumpy" is investment in the asset-type dimension? I.e., do firms tend to invest in a wide range of asset types or just a few?

Investment is remarkably lumpy in the asset dimension, with over half of the firms in the ACES sample purchasing fewer than three types of equipment and nearly $90 \%$ of firms purchasing fewer than three types of structures.

7. Is the composition of investment different during investment spikes than during periods of incremental investment?

The data show that, for most capital goods, firm investment occuring during lumpy investment episodes, or "spikes," represents a similar share of total investment as it does during periods of incremental firm investment. Computers, however, are found to account for a significantly larger share of firm invesment during incremental-investment periods than during spikes.

These results are just a first step in understanding the heterogeneity of investment across asset types at the firm level. An important next step should be exploring the dynamics of asset-specific investment. Fortunately, such research should be possible in the near future as additional surveys similar to 1998 ACES are conducted. 


\section{References}

\section{References}

[1] Abowd, John M., John Haltiwanger, Ron Jarmin, Julia Lane, Paul Lengermann, Kristin McCue, Kevin McKinney, and Kristin Sandusky. "The Relation Among Human Capital, Productivity and Market Value: Building Up From Micro Evidence ." Measuring Capital in the New Economy, Editors Carol Corrado, John C. Haltiwanger, and Daniel E. Sichel. Chicago: University of Chicago Press, forthcoming.

[2] Bresnahan, T. F., and M. Trajtenberg (1996), "General purpose technologies: 'engines of growth'?", Journal of Econometrics, Annals of Econometrics 65: 83108.

[3] Brynjolfsson, Erik, and Lorin M. Hitt. "Computing Productivity: Firm-Level Evidence." Review of Economics and Statistics 85, no. 4 (2003): 793-808.

[4] Caballero, Ricardo J., and Eduardo M.R.A. Engel. "Explaining Investment Dynamics in U.S. Manufacturing: A Generalized (S,s) Approach.” Econometrica 67, no. 4 (1999): 783-826.

[5] Caballero, Ricardo J., John C. Haltiwanger, and Eduardo M.R.A. Engel. "Aggregate Employment Dynamics: Building From Microeconomic Evidence." American Economic Review 87, no. 1 (1997): 115-37.

[6] Caballero, Ricardo J., John C. Haltiwanger, and Eduardo M.R.A. Engel. "PlantLevel Adjustment and Aggregate Investment Dynamics." Brookings Papers on Economic Activity 0, no. 2 (1995): 1-39.

[7] Caselli, Francesco, and Daniel J. Wilson. "Importing Technology." Journal of Monetary Economics 51, no. 1 (2004): 1-32.

[8] Cummins, Jason G., and Giovanni L. Violante. "Investment-Specific Technical Change in the United States (1947-2000): Measurement and Macroeconomic Consequences." Review of Economic Dynamics 5: 243-84.

[9] Davis, Steven J., John C. Haltiwanger, and Scott Schuh. Job Creation and Destruction. Cambridge, MA: MIT Press, 1996. 
[10] Doms, Mark E., and Timothy Dunne. "Capital Adjustment Patterns in Manufacturing Plants." Review of Economic Dynamics 1, no. 2 (1998): 409-29.

[11] Dunne, Timothy, Lucia Foster, John C. Haltiwanger, and Kenneth Troske. "Wage and Productivity Dispersion in U.S. Manufacturing: The Role of Computer Investment." Journal of Labor Economics 22, no. 2 (2004): 397-429.

[12] Gilchrist, Simon, Vijay Gurbaxani, and Robert Town. "Productivity and the PC Revolution." Mimeo (2003).

[13] Haltiwanger, John C. "Measuring and Analyzing Aggregate Fluctuations: The Importance of Building From Microeconomic Evidence." Federal Reserve Bank of St. Louis Review 79, no. 3 (1997): 55-77.

[14] Jorgenson, Dale W., and Kevin J. Stiroh. "Raising the Speed Limit: U.S. Economic Growth in the Information Age." Brookings Papers on Economic Activity, no. 1 (2000): 125-212.

[15] Jovanovic, Boyan, and Peter Rousseau. "General Purpose Technologies." NBER Working Paper 11093 (2005).

[16] Jovanovic, Boyan, and Dmitriy Stolyarov. "Optimal Adoption of Complementary Technologies." American Economic Review 90, no. 1 (2000): 15-29.

[17] Oliner, Stephen D., and Daniel E. Sichel. "The Resurgence of Growth in the Late 1990s: Is Information Technology the Story?" Journal of Economic Perspectives 14, no. 4 (2000): 3-22.

[18] Power, Laura. "The Missing Link: Technology, Investment, and Productivity." Review of Economics and Statistics 80, no. 2 (1998): 300-313.

[19] Wilson, Daniel J. "IT and Beyond: The Contribution of Heterogeneous Capital to Productivity." Federal Reserve Bank of San Francisco Working Paper 2004-13 (2004). 
Figure 1

A. Distribution of number of equipment types for which a firm has non-zero investment

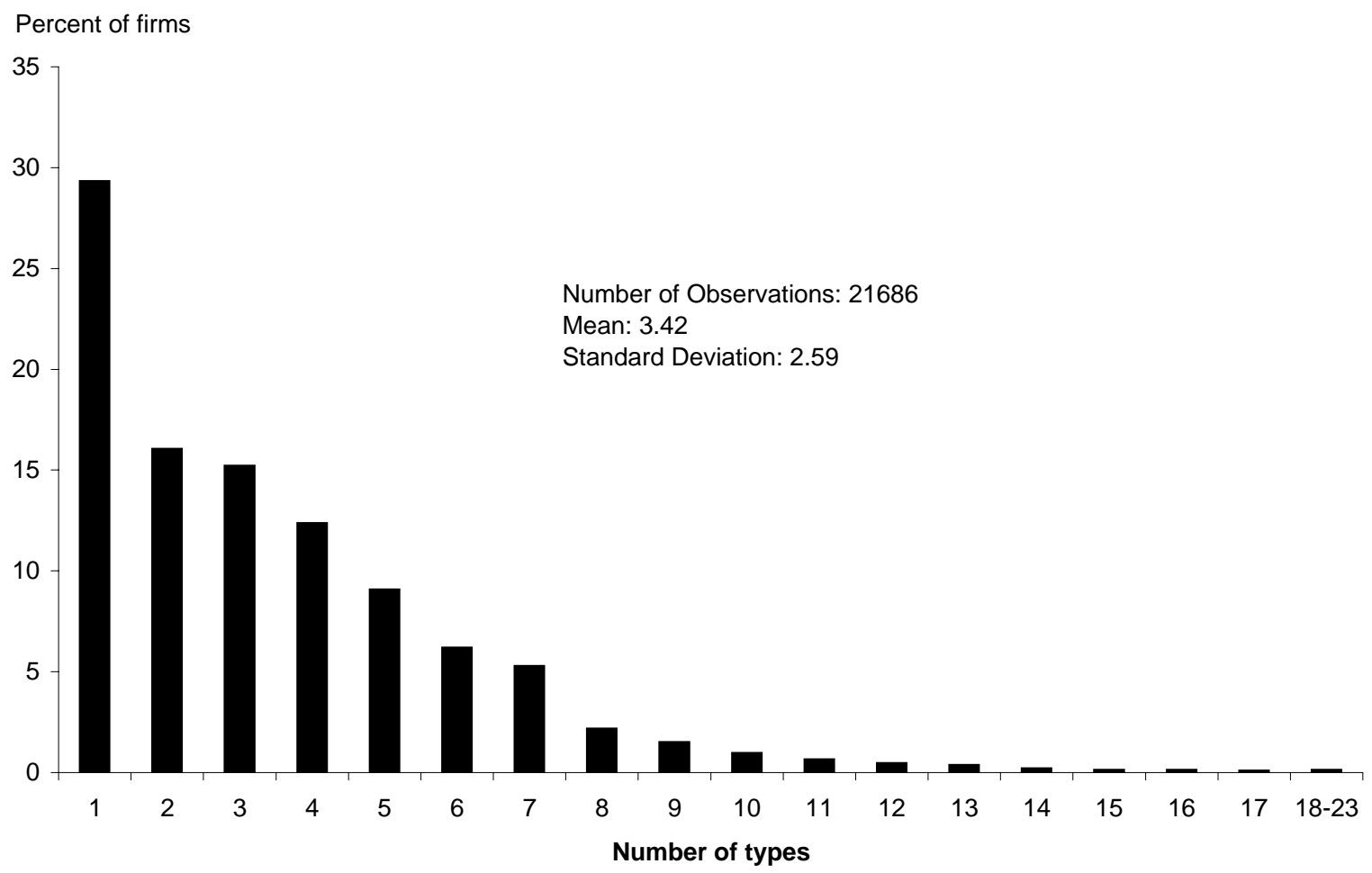

B. Distribution of number of structure types for which a firm has non-zero investment

Percent of firms

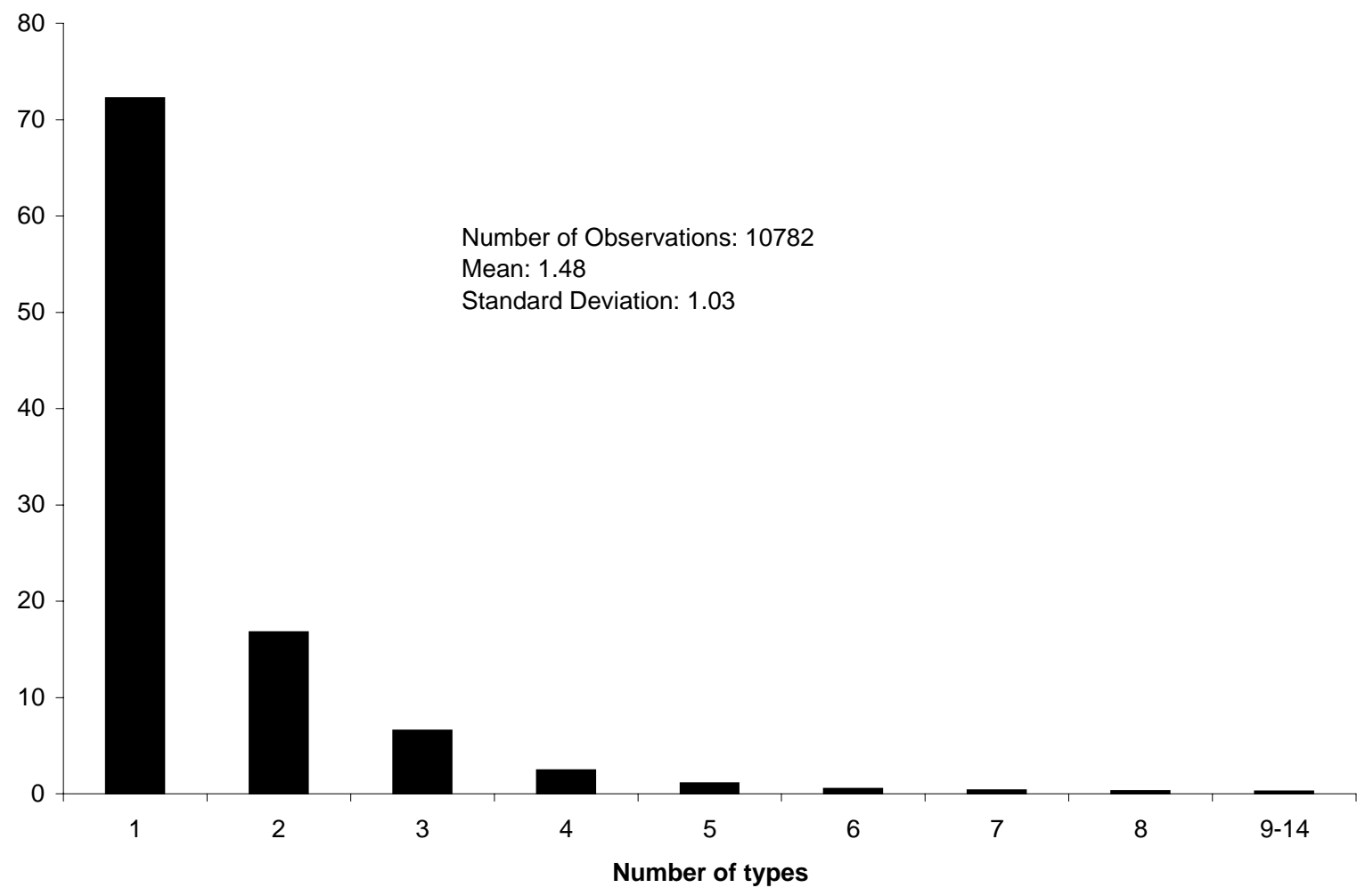


Table 1. Mean investment share and \# of firms with positive investment, by capital type

\begin{tabular}{|c|c|c|c|c|c|c|c|}
\hline \multirow[b]{2}{*}{ Type } & \multirow[b]{2}{*}{ Description } & \multirow{2}{*}{$\begin{array}{c}\% \text { of sample with } \\
\text { positive } \\
\text { investment } \\
(1)\end{array}$} & \multirow{2}{*}{$\begin{array}{c}\% \text { of sample (conditional on } \\
\text { positive investment at the } \\
\text { broad asset level) with } \\
\text { positive investment } \\
\text { (2) }\end{array}$} & \multicolumn{2}{|c|}{ Share of Total Investment } & \multicolumn{2}{|c|}{$\begin{array}{c}\text { Share of Broad Asset } \\
\text { (Equipment or Structures) } \\
\text { Investment }\end{array}$} \\
\hline & & & & $\begin{array}{c}\text { Weighted Mean } \\
\text { (3) }\end{array}$ & \begin{tabular}{|c|} 
Std. Deviation \\
$(4)$
\end{tabular} & $\begin{array}{c}\text { Weighted Mean } \\
(5)\end{array}$ & $\begin{array}{c}\text { Std. Deviation } \\
(6)\end{array}$ \\
\hline 311 & Computer and Peripheral Equipment & $55.4 \%$ & $70.8 \%$ & 0.320 & 0.416 & 0.324 & 0.418 \\
\hline 331 & Cars and Light Trucks & $23.9 \%$ & $30.5 \%$ & 0.126 & 0.303 & 0.128 & 0.304 \\
\hline 351 & Furniture and Related Products & $30.9 \%$ & $39.5 \%$ & 0.079 & 0.235 & 0.082 & 0.238 \\
\hline 141 & Office, Bank, and Professional Buildings & $15.1 \%$ & $19.3 \%$ & 0.077 & 0.184 & 0.243 & 0.418 \\
\hline 312 & $\begin{array}{l}\text { Office Equipment Except Computers and } \\
\text { Peripherals }\end{array}$ & $24.3 \%$ & $31.1 \%$ & 0.062 & 0.209 & 0.063 & 0.210 \\
\hline 131 & $\begin{array}{l}\text { Manufacturing, Processing, and Assembly } \\
\text { Plants }\end{array}$ & $12.3 \%$ & $15.7 \%$ & 0.052 & 0.174 & 0.163 & 0.358 \\
\hline 324 & General Purpose Machinery ${ }^{1}$ & $15.7 \%$ & $20.0 \%$ & 0.051 & 0.196 & 0.052 & 0.198 \\
\hline 152 & Stores - Food Related & $3.1 \%$ & $4.0 \%$ & 0.048 & 0.167 & 0.108 & 0.308 \\
\hline 155 & Other Commercial Stores/Buildings, NEC & $1.8 \%$ & $2.2 \%$ & 0.045 & 0.166 & 0.093 & 0.287 \\
\hline 323 & Special Industrial Machinery & $16.1 \%$ & $20.6 \%$ & 0.045 & 0.190 & 0.045 & 0.192 \\
\hline 315 & Medical Equipment and Supplies & $8.0 \%$ & $10.2 \%$ & 0.042 & 0.192 & 0.043 & 0.193 \\
\hline 313 & $\begin{array}{l}\text { Communications, Audio, and Video } \\
\text { Equipment }\end{array}$ & $21.2 \%$ & $27.1 \%$ & 0.036 & 0.154 & 0.037 & 0.157 \\
\hline 334 & Other Transportation Equipment & $7.8 \%$ & $10.0 \%$ & 0.030 & 0.155 & 0.030 & 0.156 \\
\hline 354 & Service Industry Equipment & $5.8 \%$ & $7.5 \%$ & 0.030 & 0.162 & 0.031 & 0.165 \\
\hline 154 & $\begin{array}{l}\text { Warehouses and Distribution Centers } \\
\text { (except Passenger) }\end{array}$ & $4.3 \%$ & $5.6 \%$ & 0.027 & 0.118 & 0.074 & 0.249 \\
\hline 111 & Residential Structures & $1.4 \%$ & $1.8 \%$ & 0.027 & 0.139 & 0.038 & 0.182 \\
\hline 332 & Heavy Duty Trucks & $5.7 \%$ & $7.3 \%$ & 0.026 & 0.148 & 0.026 & 0.148 \\
\hline 353 & Construction Machinery & $3.5 \%$ & $4.5 \%$ & 0.026 & 0.151 & 0.026 & 0.151 \\
\hline 322 & Metalworking Machinery & $6.1 \%$ & $7.8 \%$ & 0.024 & 0.144 & 0.024 & 0.145 \\
\hline 151 & Automotive Facilities & $1.2 \%$ & $1.5 \%$ & 0.024 & 0.122 & 0.051 & 0.218 \\
\hline 162 & Special Care Facilities & $2.4 \%$ & $3.0 \%$ & 0.023 & 0.117 & 0.039 & 0.185 \\
\hline 171 & Amusement and Recreational Facilities & $1.1 \%$ & $1.4 \%$ & 0.018 & 0.102 & 0.027 & 0.144 \\
\hline 355 & Other Miscellaneous Equipment & $5.3 \%$ & $6.7 \%$ & 0.018 & 0.122 & 0.018 & 0.125 \\
\hline 361 & Artwork, Books, and Other Equipment, NEC & $5.8 \%$ & $7.4 \%$ & 0.017 & 0.118 & 0.018 & 0.119 \\
\hline 201 & $\begin{array}{l}\text { Preschool, Primary/Secondary, and Higher } \\
\text { Education Facilities }\end{array}$ & $0.8 \%$ & $1.0 \%$ & 0.017 & 0.113 & 0.022 & 0.143 \\
\hline 352 & Agricultural Equipment & $2.0 \%$ & $2.5 \%$ & 0.014 & 0.110 & 0.014 & 0.111 \\
\hline 121 & Hotels, Motels, and Inns & $0.8 \%$ & $1.0 \%$ & 0.012 & 0.096 & 0.016 & 0.125 \\
\hline 153 & Multi-Retail Stores & $1.8 \%$ & $2.3 \%$ & 0.010 & 0.075 & 0.025 & 0.151 \\
\hline 343 & Electrical Equipment, NEC & $3.0 \%$ & $3.9 \%$ & 0.010 & 0.095 & 0.010 & 0.095 \\
\hline
\end{tabular}




\begin{tabular}{|c|c|c|c|c|c|c|c|}
\hline 321 & TFahricated Metal Products & $39 \%$ & ed) & I & ח & | & 0 \\
\hline 316 & Capitalized Software Purchased Separately & $13.6 \%$ & $34.9 \%$ & 0.008 & 0.063 & 0.008 & 0.064 \\
\hline 314 & $\begin{array}{l}\text { Navigational, Measuring, Electromedical, } \\
\text { and Control Instruments }\end{array}$ & $3.9 \%$ & $9.9 \%$ & 0.008 & 0.077 & 0.008 & 0.077 \\
\hline 192 & Electric, Nuclear, and Other Power Facilities & $1.1 \%$ & $2.7 \%$ & 0.007 & 0.072 & 0.009 & 0.094 \\
\hline 223 & Other Non-building Structures, NEC & $1.7 \%$ & $4.5 \%$ & 0.006 & 0.059 & 0.018 & 0.122 \\
\hline 161 & Hospitals & $2.7 \%$ & $6.8 \%$ & 0.006 & 0.055 & 0.013 & 0.109 \\
\hline 191 & Telecommunication Facilities & $0.6 \%$ & $1.5 \%$ & 0.005 & 0.057 & 0.014 & 0.116 \\
\hline 112 & Manufactured (Mobile) Homes & $0.1 \%$ & $0.2 \%$ & 0.005 & 0.058 & 0.007 & 0.070 \\
\hline 142 & Medical Offices & $1.8 \%$ & $4.7 \%$ & 0.005 & 0.048 & 0.018 & 0.130 \\
\hline 202 & $\begin{array}{l}\text { Special School and Other Educational } \\
\text { Facilities }\end{array}$ & $0.3 \%$ & $0.8 \%$ & 0.003 & 0.046 & 0.004 & 0.062 \\
\hline 181 & $\begin{array}{l}\text { Air, Land, and Water Transportation } \\
\text { Facilities }\end{array}$ & $1.2 \%$ & $3.1 \%$ & 0.002 & 0.034 & 0.007 & 0.079 \\
\hline 344 & $\begin{array}{l}\text { Mining and Oil and Gas Field Machinery and } \\
\text { Equipment }\end{array}$ & $1.2 \%$ & $3.2 \%$ & 0.002 & 0.044 & 0.002 & 0.045 \\
\hline 212 & Petroleum and Natural Gas Wells & $0.3 \%$ & $0.8 \%$ & 0.002 & 0.033 & 0.002 & 0.048 \\
\hline 342 & $\begin{array}{l}\text { Electrical Transmission and Distribution } \\
\text { Equipment }\end{array}$ & $2.0 \%$ & $5.1 \%$ & 0.001 & 0.026 & 0.001 & 0.027 \\
\hline 222 & Highway and Street Structures & $0.4 \%$ & $1.1 \%$ & 0.001 & 0.024 & 0.002 & 0.045 \\
\hline 193 & $\begin{array}{l}\text { Water Supply, Sewage, and Waste Disposal } \\
\text { Facilities }\end{array}$ & $0.6 \%$ & $1.5 \%$ & 0.001 & 0.024 & 0.002 & 0.035 \\
\hline 333 & Aerospace Products and Parts & $1.5 \%$ & $3.8 \%$ & 0.001 & 0.026 & 0.001 & 0.026 \\
\hline 213 & Other Mining and Well Construction & $0.2 \%$ & $0.6 \%$ & 0.001 & 0.022 & 0.001 & 0.034 \\
\hline 341 & $\begin{array}{l}\text { Engine, Turbine, and Power Transmission } \\
\text { Equipment }\end{array}$ & $0.9 \%$ & $2.3 \%$ & 0.001 & 0.021 & 0.001 & 0.021 \\
\hline 132 & Industrial Nonbuilding Structures & $0.5 \%$ & $1.3 \%$ & 0.001 & 0.016 & 0.002 & 0.040 \\
\hline 203 & Religious Buildings & $0.1 \%$ & $0.2 \%$ & 0.000 & 0.013 & 0.000 & 0.021 \\
\hline 221 & Conservation and Control Structures & $0.2 \%$ & $0.5 \%$ & 0.000 & 0.004 & 0.000 & 0.011 \\
\hline 204 & Public Safety Buildings & -- & -- & 0.000 & 0.006 & 0.000 & 0.007 \\
\hline 211 & Mine Shafts & $0.1 \%$ & $0.1 \%$ & 0.000 & 0.005 & 0.000 & 0.008 \\
\hline 345 & $\begin{array}{l}\text { Floating Oil and Gas Drilling and Production } \\
\text { Platforms }\end{array}$ & $0.1 \%$ & $0.2 \%$ & 0.000 & 0.002 & 0.000 & 0.003 \\
\hline 346 & Nuclear Fuel & $0.1 \%$ & $0.2 \%$ & 0.000 & 0.001 & 0.000 & 0.001 \\
\hline
\end{tabular}

Note: Total number of sample firms is 27,712 . Of these, 21,686 had non-zero equipment investment and 10,782 had non-zero structures investment. Weights used in means are inverse sampling probabilities.

1. The full name of this category is "Ventilation, Heating, Air-Conditioning, Commercial Refrigeration, and Other General Purpose Machinery" 
Table 2. Concentration of Type-Specific Investment among Industries

Top 4 Industries' Concentration Ratio

\begin{tabular}{|c|c|c|}
\hline \multicolumn{3}{|c|}{ Equipment } \\
\hline 311 & Computer and Peripheral Equipment & 0.2412 \\
\hline 316 & Capitalized Software Purchased Separately & 0.2595 \\
\hline 312 & Office Equipment Except Computers and Peripherals & 0.2794 \\
\hline 324 & $\begin{array}{l}\text { Ventilation, Heating, Air-Conditioning, Commercial Refrigeration, and } \\
\text { Other General Purpose Machinery }\end{array}$ & 0.3187 \\
\hline 351 & Furniture and Related Products & 0.3757 \\
\hline 323 & Special Industrial Machinery & 0.3847 \\
\hline 361 & Artwork, Books, and Other Equipment, NEC & 0.3922 \\
\hline 321 & Fabricated Metal Products & 0.4234 \\
\hline 355 & Other Miscellaneous Equipment & 0.4487 \\
\hline 314 & Navigational, Measuring, Electromedical, and Control Instruments & 0.4512 \\
\hline 334 & Other Transportation Equipment & 0.5213 \\
\hline 354 & Service Industry Equipment & 0.5284 \\
\hline 352 & Agricultural Equipment & 0.5782 \\
\hline 332 & Heavy Duty Trucks & 0.5976 \\
\hline 353 & Construction Machinery & 0.6677 \\
\hline 343 & Electrical Equipment, NEC & 0.6697 \\
\hline 344 & Mining and Oil and Gas Field Machinery and Equipment & 0.7137 \\
\hline 322 & Metalworking Machinery & 0.7280 \\
\hline 315 & Medical Equipment and Supplies & 0.7859 \\
\hline 331 & Cars and Light Trucks & 0.8331 \\
\hline 333 & Aerospace Products and Parts & 0.8570 \\
\hline 313 & Communications, Audio, and Video Equipment & 0.8699 \\
\hline 342 & Electrical Transmission and Distribution Equipment & 0.8993 \\
\hline 341 & Engine, Turbine, and Power Transmission Equipment & 0.9150 \\
\hline 345 & Floating Oil and Gas Drilling and Production Platforms & 0.9915 \\
\hline & Median (all equipment types) & 0.5782 \\
\hline
\end{tabular}

\begin{tabular}{|c|c|c|}
\hline \multicolumn{3}{|c|}{ Structures } \\
\hline 131 & Manufacturing, Processing, and Assembly Plants & 0.2738 \\
\hline 154 & Warehouses and Distribution Centers (except Passenger) & 0.3571 \\
\hline 141 & Office, Bank, and Professional Buildings & 0.4352 \\
\hline 223 & Other Non-building Structures, NEC & 0.5100 \\
\hline 222 & Highway and Street Structures & 0.5966 \\
\hline 221 & Conservation and Control Structures & 0.7069 \\
\hline 155 & Other Commercial Stores/Buildings, NEC & 0.7191 \\
\hline 212 & Petroleum and Natural Gas Wells & 0.7358 \\
\hline 151 & Automotive Facilities & 0.7908 \\
\hline 132 & Industrial Nonbuilding Structures & 0.8032 \\
\hline 111 & Residential Structures & 0.8067 \\
\hline 171 & Amusement and Recreational Facilities & 0.8290 \\
\hline 213 & Other Mining and Well Construction & 0.8654 \\
\hline 211 & Mine Shafts & 0.8705 \\
\hline 192 & Electric, Nuclear, and Other Power Facilities & 0.8732 \\
\hline 202 & Special School and Other Educational Facilities & 0.9028 \\
\hline 181 & Air, Land, and Water Transportation Facilities & 0.9106 \\
\hline 121 & Hotels, Motels, and Inns & 0.9114 \\
\hline 201 & Preschool, Primary/Secondary, and Higher Education Facilities & 0.9206 \\
\hline 142 & Medical Offices & 0.9242 \\
\hline 153 & Multi-Retail Stores & 0.9286 \\
\hline 193 & Water Supply, Sewage, and Waste Disposal Facilities & 0.9325 \\
\hline 112 & Manufactured (Mobile) Homes & 0.9353 \\
\hline 152 & Stores - Food Related & 0.9498 \\
\hline 162 & Special Care Facilities & 0.9653 \\
\hline 161 & Hospitals & 0.9894 \\
\hline 203 & Religious Buildings & 0.9897 \\
\hline 191 & Telecommunication Facilities & 0.9925 \\
\hline 204 & Public Safety Buildings & 0.9995 \\
\hline & Median (all structure types) & 0.8732 \\
\hline
\end{tabular}


TABLE 3. Partial correlations between Computer investment share and each other type's investment share (Sorted by correlation. Only those with correlations significant above the $\mathbf{9 9 \%}$ level are shown. Correlations control for $3-$ digit industry dummies)

\begin{tabular}{|c|l|c|}
\multicolumn{1}{|c}{ Description } & Correlation \\
\hline \begin{tabular}{|c|l|} 
Asset Type Code \\
141
\end{tabular} & Office, Bank, and Professional Buildings & 0.248 \\
314 & Navigational, Measuring, Electromedical, and Control Instruments & 0.214 \\
351 & Furniture and Related Products & 0.104 \\
312 & Office Equipment Except Computers and Peripherals & 0.086 \\
316 & Capitalized Software Purchased Separately & 0.083 \\
155 & Other Commercial Stores/Buildings, NEC & 0.072 \\
153 & Multi-Retail Stores & 0.060 \\
333 & Aerospace Products and Parts & 0.039 \\
361 & Artwork, Books, and Other Equipment, NEC & 0.030 \\
\hline 313 & Communications, Audio, and Video Equipment & -0.019 \\
344 & Mining and Oil and Gas Field Machinery and Equipment & -0.020 \\
332 & Heavy Duty Trucks & -0.022 \\
355 & Other Miscellaneous Equipment & -0.024 \\
346 & Nuclear Fuel & -0.025 \\
213 & Other Mining and Well Construction & -0.026 \\
342 & Electrical Transmission and Distribution Equipment & -0.028 \\
341 & Engine, Turbine, and Power Transmission Equipment & -0.028 \\
323 & Special Industrial Machinery & -0.028 \\
132 & Industrial Nonbuilding Structures & -0.034 \\
151 & Automotive Facilities & -0.035 \\
181 & Air, Land, and Water Transportation Facilities & -0.041 \\
192 & Electric, Nuclear, and Other Power Facilities & -0.045 \\
322 & Metalworking Machinery & -0.050 \\
212 & Petroleum and Natural Gas Wells & -0.057 \\
191 & Telecommunication Facilities & -0.070 \\
331 & Cars and Light Trucks & -0.242 \\
\hline
\end{tabular}


Table 4. Variety of Investment by Firm Size

\begin{tabular}{|r|cccc|}
\hline Decile (Sales) & 3+ Equipment Share & $\begin{array}{c}\text { Mean Number of } \\
\text { Equipment Types }\end{array}$ & 3+ Structures Share & $\begin{array}{c}\text { Mean Number of } \\
\text { Structure Types }\end{array}$ \\
\hline 1 & 24.5 & 2.07 & 4.4 & 1.23 \\
2 & 28.1 & 2.02 & 5.0 & 1.25 \\
3 & 45.0 & 2.66 & 7.3 & 1.33 \\
4 & 54.4 & 3.15 & 7.0 & 1.34 \\
5 & 60.1 & 3.55 & 8.5 & 1.41 \\
6 & 61.5 & 3.66 & 9.6 & 1.43 \\
7 & 65.1 & 3.97 & 12.7 & 1.54 \\
8 & 68.5 & 4.15 & 14.0 & 1.57 \\
9 & 68.8 & 4.21 & 17.1 & 2.06 \\
\hline 10 & 70.5 & 4.76 & 25.4 & 30 \\
\hline
\end{tabular}

Notes: The 3+ equipment (structures) share is the proportion of the sample that invested in 3 or more types of equipment (structures), conditional on having non-zero equipment (structures) investment. 